\title{
THE NEW INSTITUTIONS OF TRANSATLANTIC AVIATION
}

Yannis Karagiannis

and Adrienne Héritier

$2010 / 32$

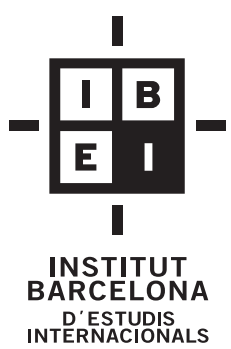

Yannis Karagiannis

Institut Barcelona d'Estudis Internacionals (IBEI)

ykaragiannis@ibei.org

Adrienne Héritier

Robert Schuman Centre for Advanced Studies, European University Institute

Adrienne.Heritier@eui.eu 


\section{IBEI WORKING PAPERS}

2010/32

The New Institutions of Transatlantic Aviation

(C) Yannis Karagiannis and Adrienne Héritier (C) IBEI, de esta edición

$\begin{array}{ll}\text { Edita: } & \text { CIDOB edicions } \\ & \text { Elisabets, } 12 \\ & \text { } 08001 \text { Barcelona } \\ & \text { Tel. } 933026495 \\ & \text { Fax. } 933022118 \\ & \text { E-mail: publicaciones@cidob.org } \\ & \text { URL: www.cidob.org }\end{array}$

Depósito legal: B-21.147-2006

ISSN:1886-2802

Imprime: Edugraf S.L.

Barcelona, November 2010 


\title{
THE NEW INSTITUTIONS OF TRANSATLANTIC AVIATION
}

\author{
Yannis Karagiannis and Adrienne Héritier
}

\begin{abstract}
This article focuses on the institutions of transatlantic aviation since 1945, and aims at extracting from this historical process topical policy implications. Using the methodology of an analytic narrative, we describe and explain the creation of the international cartel institutions in the 1940s, their operation throughout the 1950s and 60s, their increasing vulnerability in the 1970s, and then the progressive liberalization of the whole system. Our analytic narrative has a natural end, marked by the signing of an Open Skies Agreement between the US and the EU in 2007. We place particular explanatory power on (a) the progressive liberalization of the US domestic market, and (b) the active role of the European Commission in Europe. More specifically, we explain these developments using two frameworks. First, a "political limit pricing" model, which seemed promising, then failed, and then seemed promising again because it failed. Second, a strategic bargaining model inspired by Susanne Schmidt's analysis of how the European Commission uses the threat of infringement proceedings to force member governments into line and obtain the sole negotiating power in transatlantic aviation.
\end{abstract}

Key words: Trade Liberalization, Transatlantic Agreements, Aviation, Open Skies, European Politics. 


\section{Introduction}

Currently worth more than $€ 15$ billion per year, the transatlantic aviation market between Europe and the United States is not only the biggest international aviation market, but also an important source of revenue and jobs for airlines, their contractors, business firms engaged in international trade, and local communities alike. Yet, for half a century, this market was deliberately kept under-developed. Between the mid-1940s and the mid-1990s, transatlantic trade in air transport services was one of the tightest-regulated markets in the industrial world. For reasons pertaining to national security, legal consistency, and political prestige, national governments which otherwise proved their liberal credentials by successfully negotiating several trade-liberalization agreements - would not let these markets work freely. Operating multilaterally in the institutions of the International Civil Aviation Organization (hereafter "ICAO") and bilaterally through the negotiation, supervision, and sometimes denunciation of Air Services Agreements ("ASA"s), national governments exerted a "tight regulatory grip" over all matters of international aviation (Kassim and Stevens 2010: 12; see also Staniland 2003, Meunier 2005, Rhoades 2008). This was usually done in collaboration with air carriers, grouped in the International Air Transport Association ("IATA"). Operationally, IATA set routes, prices, and non-economic conditions.

What is surprising in this story is the stability and the sudden collapse of the state-centred cartel. Why was the United States ("US") willing to put up with the protectionist concerns of the Europeans for over four decades? Why did the cartel eventually collapse? Why were the US so pushy toward individual European governments as to provoke a unified European response which took the form the entry of the European Union ("EU") on the stage? Which EU internal dynamics set member governments under pressure to allow the European Commission ("Commission") to negotiate on their behalf with the US? To address these questions, this article presents an analytic narrative of the birth, behaviour, and collapse of the international (transatlantic) aviation cartel, ending with the emergence of a new institutional equilibrium with the signing of an EU/US Open skies Agreement ("OSA") in 2007. We present different explanations and point out where each does not fit important features of the empirical setting, or where making it fit requires assumptions which are contradictory with its premises. This leads us to ask new questions, seek new data, and engage in an original dialogue between the empirical record and theory.

Our discussion is organized as follows. Section 2 offers a presentation of the analytical tools we use in assessing the extant literature and in building our narrative. Section 3 reviews the recent literature and builds a preliminary narrative to identify the most relevant arguments. Section 4 addresses some of the main questions identified in the narrative, and especially those relating to the dynamics that led to the appearance of the European Commission as a significant new actor on the international aviation stage. Section 5 concludes with a number of policy implications. 


\section{Our Analytical Toolbox}

We use the concepts of (a) analytic narratives, (b) "events"; (c) equilibrium; and (d) nested games. Analytic narratives combine researchers' interest for specific historical events with social-scientific theory. (Bates et al. 1998, Levi 2004) There exist two non-mutually exclusive types of analytic narratives. The first type consists of analytic narratives which aim at adjudicating between competing historiographies. Here, the analytic narrativist assumes that historical actors are rational, and explores which of the competing historiographical claims is more consistent with that assumption (e.g. Weingast 1998). The second type aims at interpreting specific events using established social-scientific approaches. The goal is to uncover and explain issues or historical events for which we still lack some convincing explanation (e.g. Bates 1998). We start with the second type of analysis, propose an alternative explanation of events, and end up with the first type of analysis.

We focus on clearly defined events as opposed to explananda focusing on longterm, complex processes which may lead to faulty inferences because they blur different events. We rely on Riker's definition of analyzable events, defined as "the existence ... of some sort of perceived motion or action, sometime, somewhere" in a larger context of an infinitely moving reality. This presupposes imagining starts and stops. "What lies between the starts and stops we call events". Riker distinguished between (1) a situation, defined as "an arrangement and condition of movers and actors in a specified, instantaneous, and spatially extended location", and (2) an event, defined as "the motion and action occurring between an initial situation and a terminal situation such that all and only the movers and actors of the initial situation.......are included in the terminal situation." (Riker 1957)

We use the concept of Nash equilibrium (NE), which occurs where two or more players adjust their strategies to make them mutually optimal, so that no one has an incentive to unilaterally deviate from their strategy given what the others are doing (Osborne 2004: 11-52). The conversion of simultaneous games (where NEs are found) into sequential games, which may represent more accurate descriptions of reality, creates subgames, and makes some strategies non-credible. Subgame perfection and the definition of subgame perfect equilibrium serve to eliminate such strategies and therefore reduce the number of NEs (Osborne 2004: 164-68).

Finally, we also employ the perspective of nested games. Without it (i.e. when we reduce our analyses to single events), political actions may irrational. With it, it may be possible to uncover the rationality behind specific actors' actions. Hence, by linking arenas, it may emerge that the payoffs of the game in the principal arena are influenced by the prevailing conditions in the "secondary" arena (Tsebelis 1990). 


\section{The Narrative}

In our narrative of the institutionalisation and functioning of the state-sponsored aviation cartel, we focus on the reasons why the cartel institution started crumbling in the 1970s and 80s, and on the new institutions regulating transatlantic aviation that were developed following the increasing involvement of the European Commission. We build on recent political-scientific works (Kassim and Stevens 2010, Meunier 2005, Staniland 2003, Woll 2008), and use other sources (Agence Europe) only to dig deeper on specific points found in these sources.

\subsection{The Creation of a Seemingly Stable State-Centric Cartel}

Commercial aviation across the Atlantic did not develop before World War II ("WWII"). After 1945, technological innovations developed for military use were transposed to civil aircraft, and it emerged that commercial aviation would be a fastgrowth industry, including at the international level. Therefore, the Convention on International Civil Aviation, decided in Chicago in 1944 by more than 50 countries, aimed at establishing world air routes, and setting up a regulatory framework for international commercial aviation.

The 1944 negotiations were heated. On economic matters, the US advocated full liberalisation, with some restrictions on the freedom to pick and discharge traffic at intermediate points. But liberalization was opposed by the United Kingdom ("UK"), Australia, New Zealand, and to a lesser extent the Continental Europeans, all of whom advocated an international order based on absolute national sovereignty and regulation. The UK, in particular, was strongly opposed to liberalisation, because its control of numerous airports across the globe, at which most aircrafts operating international routes still had to land, gave it a formidable bargaining tool in bilateral negotiations with the US and France. The US then proposed separate agreements embodying the different extent of progress on various fronts. One of these agreements established the possibility that nations grant each other reciprocal air rights, referred to as the "Freedoms of the Air" (Rhoades 2008: 43), resulting in bilateral Air Service Agreements (ASAs). ASAs typically contained provisions on traffic rights, capacity, number of carriers to serve routes, and prices. This meant that the US could affect the strategies, and therefore the competitiveness, of those foreign carriers wishing to fly to the US. On the other hand, the US also made concessions: The Convention defined strict national sovereignty rights over airspace; created the United Nations' International Civil Aviation Organization (ICAO) to supervise agreements; and obliged the US to effectively accept a cartel - which was formed with the creation of the International Air Transport Association (IATA). The latter would stabilise prices and fix quantities, thereby limiting the scope of efficient US carriers to compete with smaller European ones.

On these legal bases, the bilateral inter-governmental ASAs rapidly proliferated and fixed all "market" conditions. The most influential of them was the Bermuda agreement, signed in 1946 between the US and the UK. The defining feature of these 
agreements was the "nationality clause", which restricted access to two countries to carriers owned by nationals of the two contracting states only.

These anti-competitive ASAs mirrored the conditions within most countries. In the UK, for example, the two largest carriers, BOAC and BEA, were nationalized in 1946, and allowed to engage in market-sharing agreements. In France, the 1945 wave of nationalizations saw the creation of Air France, which received a monopoly over the management of the entire French air transport network, and benefited from monopolistic regulation (especially from 1963 to 1986). Even in ordo-liberal Germany, Lufthansa was under state ownership, and air transport was exempt from the normal application of antitrust rules. In the US, where carriers were private, the Civil Aeronautics Board $(" \mathrm{CAB}$ ") regulated both entry and prices. Crucially, it was also responsible for the antitrust scrutiny of international agreements and mergers. Hence, restrictive as the ASAs may have been, they were not more so than national rules and regulations.

\subsection{The Appearance of Threats to the Stability of the Cartel}

Over the 1950s and 1960s the equilibrium reached in Chicago seemed extremely stable, as no country had an incentive to unilaterally defect from it. With hindsight, however, we can identify a number of factors which eventually led to its destabilisation.

First, in 1950 Pan Am, one of the main two US carriers engaged in international operations, invented the "economy class" and signalled its intention to cut prices. Second, in 1955, Delta Air Lines invented a new airline business model, the hub-andspoke model ("HSM"). HSM was (and still is) an efficient system of connections arranged like a chariot wheel, in which all traffic moves along spokes connected to a central hub. Thus, a carrier flies passengers from a set of "spoke" airports through a central "hub", where passengers change planes and then fly to their outbound destinations. This system increases traffic volume between the spoke airports and the hub, which in turn increases the load factor (passenger/seat ratio) of aircrafts. This makes the use of comparatively cheaper large aircraft profitable, and thus spreads flight-specific fixed costs. Given the cost structure of carriers ${ }^{1}$, HSM contributes to economies of scope. (Economies of scope occur when a multi-product firm can produce a given quantity of goods at a lower total cost than separate firms.) In international aviation, the average cost of a multi-product carrier decreases with 'horizontal growth', i.e. with the number of origin-destination pairs it serves, precisely the function of the HSM. Thus, the fast spread of the HSM affected the cost structure of carriers, hence their incentives to consolidate, and hence the preferences of big and financially healthy US carriers in favour of trade liberalization.

\footnotetext{
. The bulk of costs of carriers fall under three categories: (a) fixed overhead costs (e.g. general and administrative expenses, advertising); (b) flightsensitive costs, a function of the number of flights (e.g. fuel); and (c) traffic-sensitive costs, a function of the number of passengers (e.g. food). Once a schedule is set, only traffic-sensitive costs are variable. This, combined with the sheer price of aircraft, makes aviation a capital intensive industry. Hence, a carrier operating short of capacity must cover at least its variable costs by disposing of unsold seats at a low price. This creates a strong incentive to reduce prices and even risk price wars, which in turn means that carriers are particularly vulnerable to cyclical lows in demand. Hence the incentive to form cartels (private or public).
} 
Third, several developments in Europe created frictions in the cartel. The German carrier Lufthansa was re-created in 1955, thus putting pressure on the existing Dutch carrier KLM (which could not rely on its small domestic market, and had therefore heavily invested in Germany). KLM successfully pressed for improved conditions in the Dutch-American ASA. This made US carriers more conscious of international politics, and Europeans more aware of (a) American politics, and (b) the competition in which they were put by the system of bilateral ASAs. When, in 1958, France asked for the recognition of the principle of reciprocity, as well as the right to fly to the West Coast and then on to the Pacific, the US refused. France accused the US of developing a hypocritically liberal rhetoric, which failed to mask protectionist policies favouring Pan Am and TWA. The protracted negotiations that followed ended up with the (ephemeral) denunciation of the 1946 ASA by the French government.

\subsection{The Mixed Signals of the 1970 s}

In the 1970s the stability of the international cartel was subject to two important exogenous shocks. First, the introduction of wide-body jets around 1970 led to big increases in efficiency - but only for those carriers which could invest in the new technology, which was not the case for BOAC, therefore, favouring the continuation of the regulated cartel. Combined with the effect of the oil crisis and the enduring crisis regarding rights to fly over the Pacific, this put insurmountable pressure on the original 1946 Bermuda ASA between the US and the UK. The UK asked for (1) tighter controls on capacity; (2) the end of double designation (i.e. the authorization of services by more than one airline per country on a particular route), (3) the curb on Fifth Freedom rights ${ }^{2}$ exercised by Pan Am and TWA through Heathrow, and (4) rights to fly to more US cities for British carriers. The new ("Bermuda II") agreement of 1977 was favourable to these British demands. Coupled with the extraordinary importance of Heathrow in the transatlantic aviation market, it enabled the UK to resist subsequent calls for liberalisation by the US.

Second, from 1978 onwards the US domestic market was fully liberalized. The $\mathrm{CAB}$ and its anti-competitive regulatory policies were phased out and the organisation was absorbed by the Department of Transportation in 1985. (Crucially, responsibility for international aviation was first passed on to the Department of Justice. Only in 1984 did Transportation receive that portfolio, over which Justice continued to claim authority.) The end of entry and price regulation initiated a competitive era of industry growth, coupled with frequent price wars and numerous reorganisation bankruptcy filings. It also meant that the US had to re-negotiate their ASAs to allow for more US firms on each route. But, it was unlikely that the UK or France would allow three our four US carriers to operate commercial flights in exchange of the same rights for the same single state-owned airline.

2. The right of a carrier of country $X$ to land in an airport of country $Y$ to fly on to country $Z$. 


\subsection{The Increasing Involvement of the European Commission}

As the US proceeded to the full-scale domestic liberalisation, in Europe the Commission took important liberalising initiatives, too. Although neither the 1985 Commission White Paper on the Completion of the Internal Market nor the 1986 Single European Act were long on aviation, a tacit alliance between the Commission and the European Court of Justuce (ECJ) allowed the former to force the hand of national governments into accepting three legislative packages. Taken together, these packages formed the basis of a pro-competitive European aviation policy. Coupled with a series of important liberalising rulings by the ECJ, the commercialisation of public carriers, and the development of an important low-cost industry, they helped create a competitive European market. In transatlantic aviation, however, the role of the EU was very limited. In a 1994 ruling the ECJ held that international agreements on air transportation did not fall under the Community's trade policy competence because they were covered by separate articles in the EU Treaty.

The combination of an increasingly unified market within Europe and the absence of a negotiating mandate for the Commission meant that the US could still attempt to divide and rule the Europeans by proposing individual agreements. Yet, since the British would not negotiate more rights to Heathrow for US carriers, the new US "Open Skies" initiative of the 1990s started from the Netherlands. The US strategy was to gain foot in Amsterdam's Schiphol, from where it threatened to divert international traffic outbound from the UK, France, and of course Germany. Thus, unless these countries signed their own OSA with the US, their carriers would lose business to KLM and to US carriers. Further, in order to lure the Dutch into the plan, the US reminded them that their international cost-saving and market-enlarging alliance with Northwest Airlines benefited from an antitrust immunity which was not set in stone.

The American plan worked. A "domino effect" (Meunier 2005) swept across the EU, reaching first small countries. The US signed bilateral OSAs with the Netherlands (1992), and then Belgium, Luxembourg, Denmark, Finland, and Austria (1995). The Commission protested loudly, arguing that a series of small bilateral OSAs would endanger the unity of the European market and prevent the possibility of Europeinternal mergers. It also pointed out that the US were only seeking access to other European towns (mainly through Amsterdam and Brussels), but in return did not offer the right to cabotage between American towns. Nevertheless, in the Transport Council that followed a large majority rejected Transport Commissioner Kinnock's proposal of negotiating a Community OSA with the US, and insisted on maintaining national authority in this field. On the other hand, most national governments did concede to respect principles set out at the Community level when concluding bilateral agreement. A working group was charged to lay down such principles both for prohibited and compulsory clauses. 


\subsection{The EU Battle over the Commission's Negotiating Powers and the OSA of 2007}

Despite its initial failure, the Commission maintained its endeavours and restated its claim to exclusive competency to negotiate OSAs, pointing to the dangers of bilaterals for the functioning of the single market. The DGs unanimously adopted a draft negotiation agreement for the June Council 1995 as a "positive response to the US effort - which they frankly admit - to divide Europe" (Agence Europe 26/04/1995). The draft called for a complete mutual opening of both air markets, i.e. true reciprocity in market access, ownership and control, fair competition and dispute settlement mechanisms. Kinnock also threatened that if the Transport Council would reject Community negotiations and the six Member States in question would sign bilateral OSAs, the Commission would initiate legal proceedings against these member states. In spite of a last "letter of warning" from the Commission, Belgium, Luxembourg, Austria, and Finland signed OSAs in May 1995, and Sweden and Denmark initiated negotiations. Austria, Luxembourg and Finland, Belgium, Denmark and Sweden were already the subject of infringement proceedings. The UK, too, signed an agreement with the US to allow for new routes in their respective skies, and, in consequence, received a letter of warning.

It wasn't but one year later that a Community approach gained ground with some member states (e.g. Germany, the Netherlands, Italy). The Italian Council Presidency in March 1996 came out in favour of an "Overall Community Approach" extending to competition rules, state aid, air safety, air traffic management and environmental protection, and suggesting a "common EU/US aviation area" going far beyond the goals of the bilateral OSAs. The great majority of Member States requested more clarity on the objective, content and exact scope of an eventual agreement. One exception was the UK, which rejected the very principle of joint negotiations with the US.

This rejection was underlined by the simultaneous announcement of an alliance between British Airways and American Airlines with the purpose of code-sharing, and a wider commercial cooperation on prices and flight coordination. Since US antitrust authorities generally made the authorizing of an alliance conditional on the prior agreement of an OSA, the Commission was alarmed. It immediately stated that it had a duty to examine this alliance "as any other alliance contracted with European airline companies so as to ensure that their provisions are compatible with the rules of competition of the Treaty." (Agence Europe 13/06/1996)

In the meantime, the Commission had followed through its threat of initiating infringement proceedings and sent out letters of formal notice to eight member states (Austria, Belgium, Denmark, Finland, Germany, Luxembourg, Sweden and the UK). With the dangling sword of an ECJ ruling above their heads, the Transport Council in July 1996 yielded and gave the Commission a limited mandate to negotiate a transatlantic agreement in technical issues (but not on traffic rights). In return, the Commission suspended the eight infringement proceedings. 
All the while the Commission pursued its efforts to obtain a mandate to negotiate traffic rights and entered in direct consultations with the Americans which, in turn, referred Kinnock back to the Council. Transport ministers, however, rejected the Commission proposal in October 1997. France, Italy, Spain and Portugal were opposed, the Netherlands and the Scandinavian countries in favour, and Germany and the UK not clear. Compounding the situation, four member states (UK, France, Italy and Spain) negotiated bilateral agreements with the US. Given the Council's renewed refusal to extend the negotiating brief to traffic rights, resumed the infringement proceedings against the eight member states that had concluded OSAs. Some governments chastised the Commission's "strategizing"

If the Commission continues on this counter-productive road, then we shall never give our agreement to a new mandate...Germany does not agree with the Commission's argument whereby the bilateral OSAs are incompatible with European law. The Commission was consulted before the conclusion of the agreement between Germany and the US, and, at the time of signing, Mr Kinnock personally gave me his agreement. We have the approval of the European Commission (Wissman - Transport minister, Germany, Agence Europe 17/03/1998).

DG Competition held against this view that the bilateral agreements introduced discrimination between carriers by carving up the market and thus restricting competition. He underlined the inconsistency that airlines pressed their governments to conclude OSAs with the US, but then complained to the Commission when - due to the bilaterals - they could no longer access airports a member state with a similar agreement.

To buttress its position, the Commission presented a report on the air transport industry in Europe in which it is shown that the OSAs' provision that air services between two signatory countries could only be operated by airlines with majorities controlled by nationals of the two signatories (nationality clause), they run counter to single market rules; and prevent European airlines from improving their competitiveness through mergers.

In this conundrum, the decision to move to the second phase of the infringement proceedings was shifted to the end of 1998. Yet, - in spite of Kinnocks announcement that in the case of a widened brief the infringement proceedings would be suspended - the Transport Council rejected the Commission's request one more time. While the Scandinavian countries, the Netherlands, Greece, Germany, and Austria sided with the Commission, Ireland led the opposition of the other member states. Faced with the Council's renewed rebuff, the Commission moved into the third phase of the infringement proceedings against the 8 countries. After Italy had concluded an OSA with the US it was added to the list of the other 8 member states subject to an infringement proceeding.

Some member states questioned the legality of the proceedings contesting the Commission's competencies in matters of aviation relations with third countries. Rather, pursuant to Article 89 of the Treaty, the Commission must cooperate with national authorities in applying competition law. By requesting from the Council to 
adopt a Regulation ${ }^{3}$ that would allow the Commission to more severely apply competition rules to the agreements between air companies of the EU and third countries, the Commission had implicitly admitted the uncertainty of its competence.

The Commission unconvinced by these arguments, pursued its strategy. In February 1999 it sent letters of warning to the Netherlands and France because of their bilateral OSAs with the US. The incoming new transport Commissioner, Loyola de Palacio, assiduously pursued the line of action of Neil Kinnock. Backed by the Association of European Airlines (AEA), she called for a common air traffic space between the EC and the US proposed by the AEA, and invited member states to overcome "disunity, fragmentation and lack of vision" (Agence Europe 09/12/1999). To no avail, though, for when, in June 2000, the Transport Council returned to the matter it expressed satisfaction over the progress of negotiating technical matters, but sustained its opposition to the extended mandate. Member states reaffirmed the positions they had held for years: Italy supported the Commission, Ireland was radically opposed, Germany wanted to ensure that consideration was given to existing alliances, the Netherlands wished the Commission to suspend the infringement proceedings initiated in 1998.

In the meantime, the legal proceedings ran their course. In spring 2001 the ECJ heard the 8 parties brought to it by the Commission. One year later Advocate General Antonio Tizzano stated that the claim of the Commission to exclusive competence to conclude an OSA could not be founded on its alleged necessity. However, he also stated that member states could not conclude international agreements in matters covered by common rules, i.e. that airfares and reservations of US air carriers fall within Community exclusive competences. He also judged the nationality clause as contrary to rules of the right of establishment, since member states with OSAs could not grant carriers of other member states a right of establishment.

Loyola de Palacio made her third appeal for a Community negotiated OSA including traffic rights, property rules, investment and competition. She showed confidence that "Washington is well aware that the Court outcome shall mean, in any case, there is a negotiation to be made" (Agence Europe 02/05/2002). And, indeed, in November 2002 the ECJ condemned the 8 countries for violating the Commission's external competence over air fares on intra-Community routes and computerised reservations systems by concluding OSAs with the US. The Court also ruled that clauses relating to the ownership and control of airlines constitute an infringement of the principle of establishment.

The US government very quickly drew the consequences and called for an amendment of the bilateral OSAs, but stopped short of negotiations with EU15. In view of the Court's ruling, however, the Transport Council in June 2003 finally yielded to the Commission's demands and granted it the mandate of extended negotiations.

3. The proposal, supported by the European Parliament, had raised strong reluctances among member states. It was discarded in 1989. 


\section{The Analysis}

We focus on two questions, namely (1) the reasons why the US put so much pressure on the Europeans as to provoke their unified, antagonistic response; and (2) the EU internal conflict about the delegation negotiating powers to the Commission.

How can we explain the delegation of powers in the realm of international aviation from the EU national governments to the European Commission? If that delegation was a natural defensive reaction to excessive US aggressiveness, then why did the US not anticipate that? Or, if it was due to purely EU factors, such as the Commission's desire to take on more policy responsibilities, then how exactly did EU institutions function to produce such a result? We take up these questions in the following two sub-sections.

\subsection{The Puzzling Absence of Self-Restraint by the US}

One possible reading of the narrative is this: The US deregulated their domestic market in 1978. This, combined with the technological and commercial innovations of the 1950s, 60s, and 70s, led their carriers to lobby heavily for the opening of new transatlantic markets. Hence, the US government defected from the cartel equilibrium which had prevailed since 1944, and it did so by adopting a divide-and-rule strategy aiming at achieving maximum concessions from individual European countries. Soon enough, however, the Europeans realized the unbalanced nature of US "liberalism". Led by France, the Commission, and the ECJ, they eventually got their act together and united to negotiate with a signle, winning voice. According Kassim and Stevens, for example,

The second open skies initiative launched by the US in the 1990s ... played a major role in the battle between the Commission and the member states over the development of an external dimension to EU action. Washington's aggressive policy of divide-and-rule vis-à-vis the European governments allowed the Commission to mobilize support for, and ultimately to persuade member governments of the advantages of granting the Community a mandate to negotiate traffic rights with third countries. Its previous failed attempts suggest that, without the manoeuverings by the US, the Commission may not have been able to strategize as effectively... Its emergence as a decision-making arena and regulatory actor has established the [European] Union as an international actor in key areas of air transport and the partner (and rival?) of the US, which has been the hegemonic power in aviation since 1945. (Kassim and Stevens 2010: 7-8)

The essence of that version of the story is that the US strategy backfired. To understand the circumstances that led to a unified European response to American aggressiveness, we turn to game-theoretic models of the interaction between an incumbent (here, the US) and a potential antagonistic entrant (here, the Community represented by the Commission). We focus on the so-called "limit-pricing" model, where an incumbent firm discourages the entry of a potential competitor by lowering 
its price before entry occurs (Milgrom and Roberts 1982). The potential entrant sees low prices, infers that profits will be low if she enters, and therefore stays out. The lessons offered by the game are: the model does not fit well with the narrative, those generated by the game when limit-pricing is not a subgame perfect equilibrium, and those generated when limit pricing is rational. Even though the model does not fit empirical facts, its analysis provides new, original insights into the difficulties of the US to protect gains made from their "divide-and-rule" strategy.

In the limit-pricing model there are two suppliers: the incumbent (who we will note US) and a potential entrant (who we will call COM). The incumbent supplies services (international agreements) to a group of consumers (European non-governmental stake-holders in international aviation) at a price (e.g. some bias in favour of US carriers). If the US is the only supplier of such services, it can raise their price (make the agreements more biased in favour of US carriers). The potential entrant, on the other hand, progressively develops the capability to enter the market (receive delegated powers to negotiate with the US). It too might produce at some cost and charge a price (loss of national sovereignty, more competition rules, and regulated state subsidies). The game unfolds over two periods.

Without the danger of entry, the US will always charge a high price, meaning that consumers will have to pay a monopolistic price over both periods. With the danger of entry, however, the US face the possibility of having to divide the market equally with COM. COM must decide whether to actually enter, and for this it has to anticipate the nature of post-entry competition. If it sees the US charging a high price in period 1 (not making balanced bilateral OSA offers), it concludes that they will not be aggressive (i.e. offer improved conditions) in period 2, for otherwise they would have done so before COM's entry, precisely in order to prevent such entry. If COM is right and enters, a Cournot duopoly equilibrium prevails, whereby the US and COM share the market.

The US, on the other hand, calculates that, if COM enters, they will have to share the market with it, and hence share profits in the second period. Clearly, COM's entry is costly to the US, and for that reason they will wonder whether they can deter entry by being sufficiently accommodating to European demands so as to make COM believe that European non-governmental stakeholders will always prefer the US over COM. In the language of economics, the incumbent will consider setting a limit price in the hope of charging a monopoly price in the second period.

Considering this explanation in the light of our narrative, the first lesson is that the limit pricing model does not seem to fit well. The US could have foreseen that the Europeans would unite, delegate powers to the Commission, and thereby achieve a more balanced transatlantic deal. Thinking forward and reasoning backwards, they should have engaged in political limit pricing, offering individual European countries just enough concessions to prevent them from changing their preferences in favour of unity and delegation of power to the Commission. And yet, they did not do so. They pressed too much, this led to the involvement of the Commission, and that in turn led to a radical overhaul of the transatlantic aviation deal. 
The second lesson from this model is generated when we ask why the US may not have engaged in political limit pricing. The analysis shows that limit pricing is not a subgame perfect equilibrium. This is illustrated in the figure below, where the limit pricing equilibrium occurs only when COM's expectations about the US's post-entry pricing (i.e. OSA terms) are irrational. The incumbent (US) moves first, and can decide whether to charge a limit price $\left(\mathrm{P}_{1}\right)$, or a monopolistic price $\left(\mathrm{P}_{\mathrm{m}}\right)$. The potential entrant $(\mathrm{COM})$ moves second and can decide whether to stay out of the market (thereby sparing some of its limited political resources but foregoing the opportunity to further its budget and / or its career concern) or enter (thereby furthering it budget and/ or career concern, but also spending political capital). If COM decides to stay out, the game ends and each player receives their payoff. If $\mathrm{COM}$ decides to enter, however, US gets to move again, and can decide to offer either a competitive price $\left(\mathrm{P}_{c}\right)$, or limit price $\left(\mathrm{P}_{1}\right)$, where $\mathrm{P}_{c}<\mathrm{P}_{1}$. After the US has moved, the game ends and each player receives their payoff. Payoffs are ranked from 1 (least preferred) to 6 (most preferred) for the US, and from 1 to 3 for COM. Clearly, the limit pricing equilibrium (illustrated by the dotted bold line) is not subgame perfect. If COM enters, then the US should select $\mathrm{P}_{c}$ in period 2. In fact, the subgame perfect Nash equilibrium occurs when the US know they cannot credibly prevent the entry of COM, and therefore select $\mathrm{P}_{\mathrm{m}}$ in the first period. (The bold line in the lower half $\mathrm{f}$ the tree.) This may offer a good reason why our narrative differs from the predictions of a political limitpricing model.

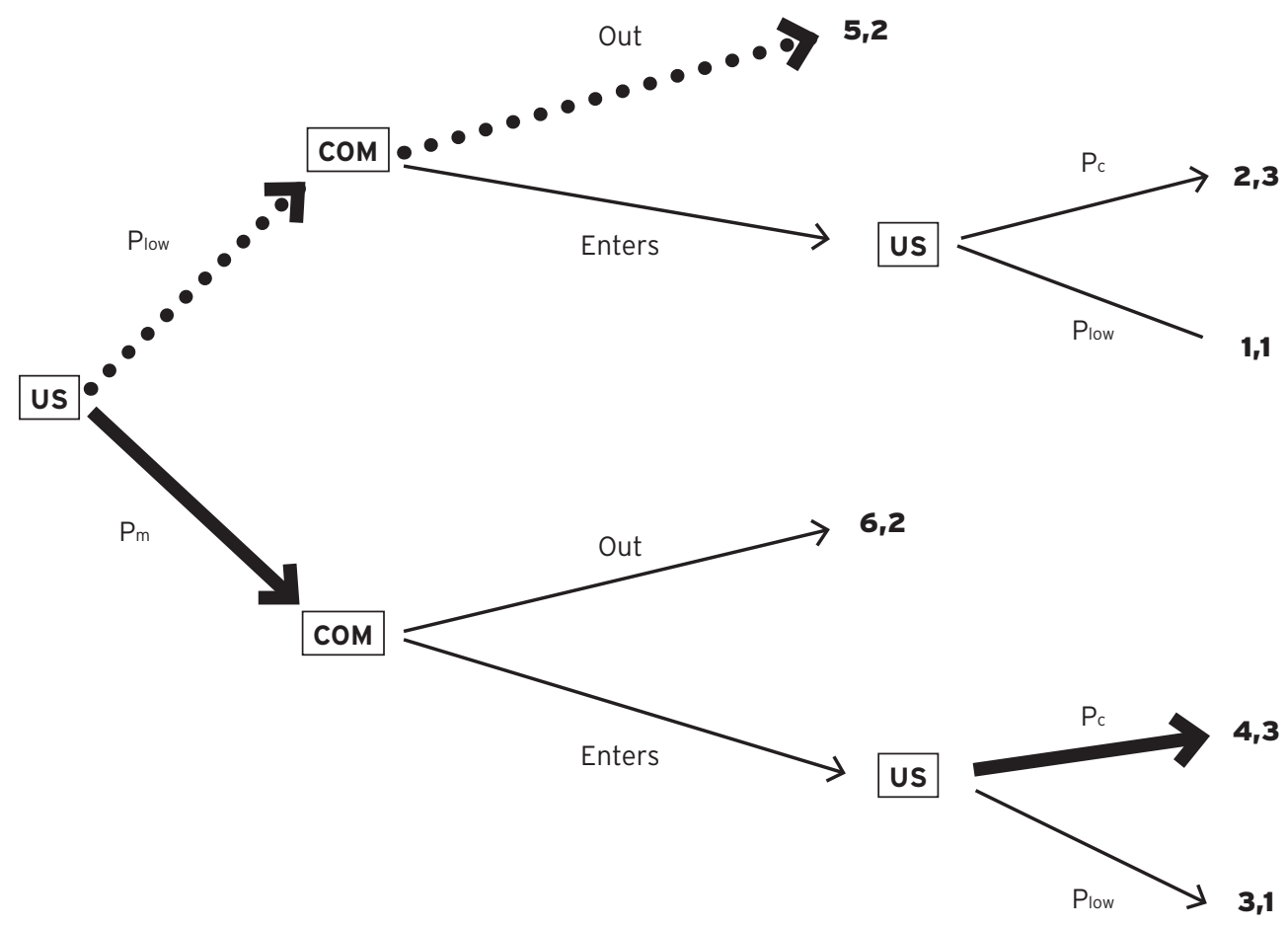

Yet, the third lesson generated from this model comes when we consider the case where limit-pricing might be rational. Generally speaking, economists agree that the logic of the limit pricing model is flawed, if only because most such games are played over more than two periods. With more periods, the US would have to engage in limit pricing in every period to constantly deter entry by COM. The promise of 
monopoly profits would be an unattainable, moving target. On the other hand, there is one case where limit pricing might make sense. This occurs when the incumbent (the US) does not need to lower its price too much to deter entry - possibly because it has a considerable cost advantage over the potential entrant. And this does seem to fit our narrative! For, as we saw in section 3, (a) most member states in the EU were extremeley reluctant to delegate ever more powers to the Commission in that area; and (b) the US could have committed to low post-entry prices.

So, if the US could profitably engage in limit offers, why do we observe the increasing involvement of the Commission from the mid-1990s onwards? Why did the US cease its limit offer strategy, ask for terms which the Europeans perceived as excessively aggressive and divisive, and thus provoke the delegation of powers to the Commission? In order to answer this question, we employ the concept of nested games. A plausible reading of this history seems to be that the US officials responsible for international aviation policy were involved simultaneously in games of international bargaining and in games of domestic politics. In particular, we from Section 3 that the DoJ has been very antagonistic to the DoT, especially after the Reagan administration had transferred the former's aviation powers to the latter in 1984. Since the DoT's payoffs in the international bargaining game depended on the prevailing conditions in the game played against the DoJ, the DoT faced a variable payoff structure.

Just as the 1982 presidential election led to a redistribution of roles in favour of DoT, the approach of the 1996 presidential election and the prospect of renewed antitrust enforcement efforts highlighted the DoJ's claim on the antitrust immunisation powers of DoT. For that reason, DoT had to act fast to (a) get the airline alliance immunities out, and (b) present a record of service to the public interest. In short, given the competition by DoJ, DoT had to accept playing the lottery of an aggressive policy in Europe. Hence, domestic political struggles led to too aggressive a policy towards the Europeans. At the same time, a similar nested game was at work in Europe, and this is what we examine in our final sub-section below.

\subsection{The European Side and the Strategising Commission}

Another possible reading of the narrative offering a theoretically-backed explanation for the new institutions of transatlantic aviation, focuses on the intra-European conflicts regarding the delegation of powers to the Commission.

The first thing we note is that the sustained conflict between the European Commission and the Member States is surprising, for two reasons. First, European Union politics is often conceptualised in terms of principal-agent relationships, including in the area of international economic negotiations (e.g. Pollack 2003, Dür and Elsig 2011). According to that conceptualisation, the national governments are the principal(s), and the Commission their agent. Yet, if that conceptualisation is right, then the principals should be devising a game for the agent to play in such a way that it furthers the principals' interest. More specifically, the principals would be offering the agent an incentive-compatible contract, which would factor in all agency costs at the time of 
contracting. After that moment, an efficient third party dispute resolution mechanism should be available to both parties, should one of them renege or seek renegotiation. And yet, what we observe in our narrative on international aviation is a very active Commission, which not only furthers its internal mandate by manipulating the rules, but also enters an alliance with the ECJ to step onto territories which had been explicitly excluded from its competencies in the Treaty! Plainly, then, the conflict we observe generates negative lessons about principal-agent models of EU politics.

The second reason why that conflict is intriguing is because the Commission seems to have acted unanimously, and against the will of several national governments. On the one hand, this seems to obey the logic of the Treaty, which declares the Commission as a whole and individual commissioners as persons to be independent from national governments. On the other hand, it remains surprising to find that a college of 27 politicians is able to (a) make non-cyclical decisions, (b) stick to them even in the face of adversity, and (c) not suffer losses in terms of cohesion, even tough some commissioners can only further their career concerns, or policy turf, with the active collaboration of national governments. From this, we retain that it may be plausible to model the Commission as a unitary actor.

In explaining the outcome on the European side (i.e. the extended negotiation brief), it is possible to conceptualize the strategic interaction between the Commission and the Council/member states as an implicit bargaining process in the shadow of the Court (see for a similar argument in telecommunications and energy Schmidt 2000). The Council had to decide unanimously, the Commission by consensus of the cabinet. The conflict at stake is a zero-sum conflict, since it is either the member states or the Commission who has the competency to negotiate an OSA.

The actors' preferences are the following: Member states/represented by the Council prefer bilaterals over joint negotiations over no action. Given the unanimity rule even the opposition of one member state would be enough to defeat the Commission's proposal in the Council. Member states preferences regarding bilaterals are strongly influenced by the prospect of seeing alliances with American carriers authorized by the US anti-trust authorities, a competence which - before the 2002 Court ruling - was not acknowledged to the Commission in aviation with third countries. The US government, in turn, made the granting of antitrust immunity contingent upon an extant bilateral OSA. The Commission prefers joint negotiations over bilaterals over no action. The formation of preferences within the Commission between the DGs Internal Market, DG Transport and Energy and DG Competition as regards the request of having joint negotiations instead of bilaterals appears not to have been subject to conflicts.

The actors dispose of the following strategies: The Commission can propose a joint negotiation mandate, or refrain from doing so, initiate infringement proceedings or refrain from doing so. The Council/member states can accept or reject the joint negotiation mandate, can conclude bilaterals or refrain from doing so. The course of interactions may summarized as follows: Member states supported by corresponding Council decisions conclude bilateral OSAs with the US. The Commission claiming the right of exclusive external trade negotiation competences with third countries 
reacts by initiating infringement procedures. The threat of a considerable number of member states being taken to Court induces the Council to at least accept a restricted negotiation mandate of the Commission in technical matters. In return, the Commission suspends the infringement proceedings.

This equilibrium ends when the Commission widens its claim for a negotiating mandate asking for its extension to the core matter, i.e. traffic rights. The Council/ member states reject the request stating that aviation agreements fall under national authority. In response the Commission resumes the infringement proceedings. When the ECJ issues its ruling condemning the member states in question for breaching Community law, the option of individual bilaterals is not viable anymore. The Council, therefore, does not have a fall-back option of bilaterals and is forced to grant the Commission its extended brief. The negotiations with a sole Community negotiator, the Commission, were launched.

\section{Conclusion}

We have described the institutions of transatlantic aviation, old and new. We have done so by creating a narrative which builds on the latest political-scientific literature and, where appropriate, on other (non-conflicting) sources. This narrative has counted the creation of the international cartel institutions in the 1940s, their operation throughout the 1950s and 60s, their increasing vulnerability in the 1970s, and then the progressive liberalization of the whole system, spurred by both US domestic liberalization and te active role of the European Commission in Europe. This story seems to have a natural end, marked by the signing of an Open Skies Agreement between the US and the EU in 2007.

Beyond offering this narrative, we have tried to extract systematic knowledge from it. To do so, we have sought to fit well-known analytic frameoworks to the history of international aviation and European politics. One such frameowk was a "political limit pricing" model, which seemed promising, then failed, and then seemed promising again because it failed. Another was the use of Susanne Schmidt's analysis of how the European Commission is able to be more than an agenda-setter in EU politics. Here, we started with certain assumption which would not have led us to consider that model, saw that they did not fit our narrative, and were therefore led to provisionally accepting Schmidt's theory.

By creating this dialogue between rich historical material and stark social-scientific theory we have sharpened our understanding of the events we wanted to describe and possibly explain. Although we have not always produced an authoritative explanation, we have highlighted what is still problematic in the mainstream narrative on transatlantic aviation, and we have thus opened the door to more focused, rigorous empirical research.

Several conclusions may be drawn as regards the policy relevance of our analysis. From the angle of the distribution of power of negotiating policy agreements 
with third countries, the Commission by forming a strategic alliance with the ECJ has successfully been able to widen its realm of competences. This has been a pattern of deepening European integration in other policy areas (e.g. energy, telecommunications), too, that most recently has called forth some criticism from the part of member governments (e.g. the ruling of the German Supreme Court in 2009).

As regards the policy gains achieved by the fact that there now is a sole European negotiator as compared to several member governments negotiating with the contracting partner, the US, the policy results are mixed at best. The outcome of the negotiation of the OSA 2007 is clearly biased in favour of the US: while American carriers enjoy the right of cabotage within Europe, European carriers do not have the same right in the US. Moreover, the Americans were not willing to loosen their ownership and control restrictions for European airlines. These biases in the outcome of the OSA 2007 negotiated by the Commission gave rise to an immediate planning of a renegotiation of OSA (stage two) which is on-going at the point of writing. 


\section{References}

Bates, R., A. Greif, M. Levi, J-L. Rosenthal, and B. Weingast. 1998. Analytic Narratives. Princeton (NJ): Princeton University Press.

Commission (European). 2007. EU-US Open Skies. A New Era in Transatlantic Aviations Starts on March 30. Available at

http://europa.eu/rapid/pressReleasesAction.do?reference=IP/08/474\&quiLan guage $=$ en

Dür, A. and M. Elsig. 2011. A Principal Agent Approach to Understanding the EU's Foreign Economic Policies. Journal of European Public Policy, 18 (3), forthcoming.

Kassim, H. and H. Stevens. 2010. Air Transport and the European Union: Europeanisation and its Limits. London: Palgrave-Macmillan.

Levi, M. 2004. An Analytic Narrative Approach to Puzzles and Problems. In I. Shapiro, R. Smith, and T. Masoud (Eds.). Problems and Methods in the Study of Politics, pp. 201-226. New York: Cambirdge University Press.

Meunier, S. 2005. Trading Voices: The European Union in International Commercial Negoatiation. Princeton (NJ): Princeton University Press.

Milgrom, P. and J.Roberts. 1982. Limit Pricing and Entry Under Incomplete Information. Econometrica, 50 (2): 443-459.

Osborne, M. 2004. An Introduction to Game Theory. New York: Oxford University Press.

Pollack, M. 2003. The Engines of European Integration. Oxford: Oxford University Press.

Rhoades, D. 2008. Evolution of International Aviation: Phoenix Rising. Aldershot: Ashgate.

Riker, W. 1957. Events and Situations. Journal of Philosophy, 54 (1): 57-70.

Schmidt, S. 2000. Only an Agenda-Setter? The European Commission's Power over the Council of Ministers. European Union Politics, 1 (1): 37-61.

Staniland, M. 2003. Government Birds: Air Transport and the State in Western Europe. Lanham (MD): Rowman \& Littlefield.

Tsebelis, G. 1990. Nested Games: Rational Choice in Comparative Politics. Berkeley: University of California Press.

Woll, C. 2008. Firm Interests: How Governments Shape Business Lobbying in Global Trade. Ithaca (NY): Cornell University Press. 